other country in the world, and school courses are often ill-adapted for their purpose in education. Now that the educationist has realized that the pupil is no empty sarcophagus into which the mummy called 'information' should be stuffed, then the objective of making use of the child's own initiative and response might be achieved. As in the world of living things, the educationist is realizing that it is the response from within and not the impression from without which counts. Another conception which is helping to direct the flow of educational practice has arisen from the difficulties and disturbances which have upset the peaceful course of national life in recent years. $\mathrm{By}$ inducing independence of thought and balance of mind, school education should lay the founda. tions of mental stability and of the appreciation of the significance of social relationships which would prepare the child for the responsibilities of citizenship.

The fundamental interest of ehildren in Nature opens up easy ways of inducing response and initiative. To be effective, biology teaching should run in graded stages throughout the whole school period, as indeed it does in many countries. Further, it should place the pupil in contact with living things, in school and out of school, as a basis for the understanding of the activities and relationships of life. Finally, it should in its later stages boldly proceed to link man with the rest of the animate world, and show how he, too, in his relation to natural environment, and to his animate or social environment, is constrained by the laws of Nature.

The difficulty of finding teachers qualified to conduct biology teaching with these ends in view, leads to the question as to whether the universities have attempted to meet the need for teachers of biology. They should introduce more of the living animal ; there should be more first-hand contact with Nature, a greater familiarity with British plants and animals, their relationships with each other and with man himself. In their glorification of research, which is often pedestrian in nature, and their belittling of school teaching, further blame must be apportioned to the universities.

Other speakers amplified three main points which arose from the addresses: the need for inculcating the right mental outlook and for developing perspective and initiative, and a condemnation of academic biology. During the discussions, one felt that a genuine attempt is being made to meet those criticisms of school science teaching which is contained in the Spens Report, and that a step forward has been made to apprehend the possibilities of biology. Prof. F. T. Brooks, University of Cambridge, suggested that the wide extension of 'refresher' courses in the universities would make a valuable contribution to meet present deficiencies.

The part played by biological education in contributing to the welfare of native societies was described by delegates from New Zealand, Australia, Africa, Malaya, West Indies, Ceylon and other parts of the Empire. Sir Frank Stockdale, agricultural adviser to the Colonial Office, emphasized the need for co-operation between education, agricultural and health officers of communities that live close to the soil. In most tropical countries, a bias is already being given to education in teaching improved methods of agriculture, personal and social hygiene, housing and sanitation. In this connexion the need for an adequate training of teachers in human biology was stressed by many of the colonial visitors.

\title{
OBITUARIES
}

Maria Ogilvie Gordon, D.B.E.

$\mathrm{D}$ AME MARIA OGILVIE GORDON died on June 24, and with her has passed a pioneer in woman's share of scientific education and research. Eldest daughter of the Rev. Alexander Ogilvie of Aberdeen, she received her schooling in Edinburgh. She then, 1889-90, studied at University College, London, where she won the gold medal for zoology and comparative anatomy under Ray Lankester. In 1893 she was awarded the London D.Sc. Meanwhile, 1891-95, she had undertaken an investigation of recent and fossil corals under Hertwig and Zittel at Munich. She could not in those days enter the University of Munich as an official student, but merely as a private research worker, receiving kindly assist. ance from the professors and others of the staff. Under these conditions she published two important papers on corals, one in the Transactions of the Royal Society and the other as a supplement to Palceonto. graphica. In recognition of their merit, sho was in 1900 granted tho $\mathrm{Ph} . \mathrm{D}$. of Munich with highest honours. The occasion was specially noteworthy because it was the first time this degree had been conferred upon a woman.

Corals led Dame Maria into other fields than zoology and palæontology. In 1891, she accompanied Baron von Richthofen on a geological excursion to the South Tyrol, and listened to him expounding his thirty-year-old application of Darwin's theory of atolls to the irregularly disposed Triassic dolomites 
of the region. Afterwards, without losing Richthofen's friendship, she contested his interpretation, and at tributed most of the seemingly capricious behaviour of the rocks to hitherto undetected thrusts. Those who recall the fate of somewhat similar criticisms of Tiddeman's reef-knolls in the Carboniferous of Great Britain may expect that a considerable proportion of Richthofen's conception will survive; but there can be little doubt of the permanent value of many of Dame Maria's contributions to the palæontology, stratigraphy and tectonics of the district. Here we may single out, as specially characteristic, her claim to have established recurrences of powerful earth movements with pronounced changes of strilse.

In the fastnesses of the Tyrol, Dame Maria suffered from more than the usual isolation of a research worker in field geology, but at home she never lacked co-operation in the discussion and presentation of her observations. In 1932, when she received the Lyell Medal of the Geological Society, she gratefully recalled help received from men like Geikie, Topley, Lapworth, Peach and Horne. Altogether, she pub. lished about thirty original works, rather more than half of them in German. British readers also will never forget her translation of Zittel's "History of Geology and Palæontology" (1901).

Dame Maria, in spite of her scientific activity, found time to take a leading part in advancing the welfare of women and children in general. She married in 1895, and had one son and two daughters, of whom the elder was christened 'Coral'.

E. B. Bailey.

\section{Sir Henry Stuart-Jones, F.B.A.}

WE regret to record the death of Sir Henry Stuart. Jones on June 29, aged serenty-two years.

Few men of learning in this generation have combined so fully the widest and most exact scholar. ship with academic statesmanship and administrative drive. Best known among students as editor of the revised "Greek Lexicon" of Liddell and Scott, Henry Stuart-Jones will be remembered among Welshmen as principal of University College, Aberystwyth, and vice-chancellor of the University of Wales.

Born on May 18, 1867, and educated at Rossall and Balliol, he had an academic career of exceptional distinction, and was elected in 1890 to a fellowship at Trinity College, Oxford, to which (after busy years of travel and study in Greece and Italy) a tutorship was added in 1894. Ho had already taken pupils at Exeter College for Henry Polham. As temporary relief from characteristic overwork, he held from 1903 until 1905 the directorship of the British School of Archxology in Rome, without severing his con. nexion with 'l'rinity; but at the end of 1905 he left Oxford and settled at Saundersfoot near Tenby, devoting himself mainly. to Roman history and antiquities.

In 1911, however, Stuart-Jones seemed the obvious man to edit a now edition of "Liddell and Scott", which involved drastic changes of plan and the organization of wide collaborated research, in which he was ably assisted (1921-37) by the late Roderick McKenzie. This great task remained a central interest for him through life.

After valuable war services to the Foreign Office, Stuart-Jones had scarcely resumed work on the "Lexicon" when the Camden chair of ancient history fell vacant by tho premature death of Francis Haver. field. Stuart-Jones could have filled any of the Oxford chairs in classics, ancient history, or archæölogy with distinction, and his inaugural lecture as Camden professor was a fine piece of research and exposition. But he published nothing further. $\mathrm{He}$ lectured mainly on the provincial administration of the Roman Empire, and was lavish of his varied learning to colleagues and advanced students. Though living still at Saundersfoot in vacations, and retaining his editorship of the "Lexicon", he took an active part in college and university business; and his appointment in 1927 as principal of the University College of IVales at Aberystwyth, though surprising to some of his friends, actually concentrated his manifold equipment and exceptional energies into a less diffuse career, though he continued to edit the "Lexicon", and rendered valuable services to the council of the British Academy.

At Aberystwyth, Stuart-Jones's rapid and intimate mastery of academic detail, and his newly won proficiency in Welsh, enabled him to take the initiative in many directions : collogo-buildings, status and salaries of his staff, courses in arts and crafts, research in agriculture and plant-breeding in the institute endowed by Sir Julien Cahn. He was vice-chancellor of the University of Wales during 1929-1931, and found time for work on the Representative Council of the Welsh Church, and in the Diocese of Saint David's.

His impressive appearance and forcible personality were, however, always ill-served by a delicate constitution; and in March 1934 he found it necessary to resign his academic work. But the "Lexicon", now nearly completed, occupied him still, and the premature death of Roderick Mickenzio throw heavy burdens on him in the last two years.

Stuart-Jones was knighted in 1933. All his three colleges elected him to honorary fellowships; he was a member of many foreign institutes, and the Society for the Promotion of Roman Studies celebrated his seventieth birthday with a complimentary volume of its Journal, with portrait and bibliography.

J. L. MYRES.

WE regret to announce the following deaths :

Brigadier-General the Hon. C. G. Bruce, C.B., M.V.O., leader of the Mount Everest Expeditions of 1922 and 1924, on July 12, aged seventy-three years.

Prof. IV. A. Jolly, profossor of physiology in the University of Cape Town and past president of the Royal Society of South Africa.

Prof. John Mellanby, F.R.S., Waynflete professor of physiology in the University of Oxford, on July 15, aged sixty years. 